\title{
Green Finance for Sustainable Development in Pakistan
}

Keywords: Green Finance, Supply \& Demand Side, Banking Sector, Fossil Fuels, Ecological Inequality.

@ 2019 by the Islamabad Policy Research Institute.

IPRI Journal $\mathbf{~ X I X ~ ( 2 ) : ~ 1 - 3 4 . ~}$

https://doi.org/10.31945/iprij.190201.

* The author is Assistant Professor at the School of Social Sciences \& Humanities, National University of Sciences \& Technology (NUST), Islamabad, Pakistan. He can be contacted at: zubair@s3h.nust.edu.pk.

** The author is Assistant Professor at the Tapia College of Business, Saint Leo University, Florida, United States. He can be contacted at: zacharyasmith@gmail.com. 
Dr Muhammad Zubair Mumtaz \& Dr Zachary Alexander Smith

\section{Introduction}

ince the Industrial Age, ecological inequality has led to carbon dioxide $\left(\mathrm{CO}_{2}\right)$ and other Greenhouse Gases (GHGs) which eventually produced global environmental issues. With the induction of technological advancements, the environment has been affected by pollution, global warming, Ozone depletion, depletion of natural resources, deforestation, and loss of diversity. ${ }^{1}$ Rapid and excessive industrialisation, without taking any precautionary measures to protect the environment as well as mismanagement of industrial projects, has created further environmental, water and health problems.

Climate change and environmental degradation have been seriously influenced by the negative effects of market activities related to production and consumption, and runaway population growth. The levels of modern production have created social costs in the form of air and water pollution. Modern patterns of consumption are heavily driven by market forces without consideration of basic ecological needs. In 2010, the International Energy Agency (IEA) conducted a critical review of total outcomes of energy-oriented $\mathrm{CO}_{2}$ emission worldwide and found that fossil fuel-based energy and climate security challenges were classified as serious issues influencing sustainable economic development. ${ }^{2}$ China is considered a case study in which environmental problems caused serious consequences. Over the past two decades, China's economic growth has been the fastest among major countries which is the prime reason why it has extensive air pollution. Across the world, 16 of the 20 most polluted cities are located in China. ${ }^{3}$ Owing to this excessive air pollution, China's

1 Ram Lakhan Singh and Pradeep Kumar Singh, "Global Environmental Problems," in Principles and Applications of Environmental Biotechnology for a Sustainable Future, ed. Ram Lakhan Singh and Ram Manohar (Singapore: Springer Science +Business Media, 2017), 13-41.

${ }^{2}$ Karl Hallding, Aaron Atteridge and Marie Jurisoo, "Together Alone? Brazil, South Africa, India, China (BASIC) and the Climate Change Conundrum," (Sweden: Stockholm Environment Institute, 2010), https://mediamanager.sei.org/documents/Publications/SEI-PolicyBrief-Olsson-BASICClimateChangeConundrum.pdf.

${ }^{3}$ Mason F. Ye, "4.2 Causes and Consequences of Air Pollution in Beijing, China," Pressbooks, ohiostate.pressbooks.pub/sciencebites/chapter/causes-and-consequences-ofair-pollution-in-beijing-china/. 
Environmental Sustainability Index is ranked near the bottom among countries worldwide. ${ }^{4}$ To combat these issues, the Chinese government has developed a comprehensive plan to deal with industrial and environmental pollution. ${ }^{5}$

Developed countries are better at managing the environmental effects caused by industrial development because the procedures that businesses have to follow are established and require adherence. While it is true that the global environmental crisis is induced by massive consumption of materials and energy in developed countries, the global environmental crisis is also perpetuated by poor regulations in developing countries. When linkages with developing countries are established via international trade, they contribute to environmental problems worldwide. The magnitude of environmental issues is considerably higher in developing countries due to non-compliance of the rules of business, broadly covering (a) disposal of industrial wastage; (b) usage of outdated machinery; (c) improper maintenance of plants and equipment; and (d) lack of accountability from governing bodies.

Using the extreme weather events and socioeconomic dataset covering 1997 to 2016, the Global Climate Risk Index identified a list of the most affected countries: Honduras, Haiti, Myanmar, Nicaragua, Philippines, Bangladesh, Pakistan, and Vietnam. ${ }^{6}$ The results also show that Haiti, Zimbabwe, Fiji, Sri Lanka, and Vietnam are the countries that were most influenced by weather and climate change in 2016 as they registered as high risk countries on the Index. The analysis also reports that developing countries are generally affected more by high climate risk when compared with industrialised countries as they do not comply with

4 Jianguo Liu and Jared Diamond, "Revolutionizing China's Environmental Protection," Science 319, January 4, 2008, doi: 10.1126/science.1150416, 37-38.

5 Yana Jin, Henrik Andersson and Shiqiu Zhang, "Air Pollution Control Policies in China: A Retrospective and Prospects," International Journal of Environmental Research and Public Health 13, no. 12 (2016), doi: 10.3390/ijerph13121219.

6 David Eckstein, Vera Künzel and Laura Schäfer, "Global Climate Risk Index - Who Suffers Most from Extreme Weather Events? Weather-related Loss Events in 2016 and 1997 to 2016," (paper, Germanwatch, 2018), https://germanwatch.org/sites/germanwatch.org/files/publication/20432.pdf. 
Dr Muhammad Zubair Mumtaz \& Dr Zachary Alexander Smith

the appropriate measures to safeguard the environment, thereby, creating severe problems. 
Green Finance for Sustainable Development in Pakistan

Figure-1

$\mathrm{CO}_{2}$ Emissions (Metric Tonnes Per Capita)

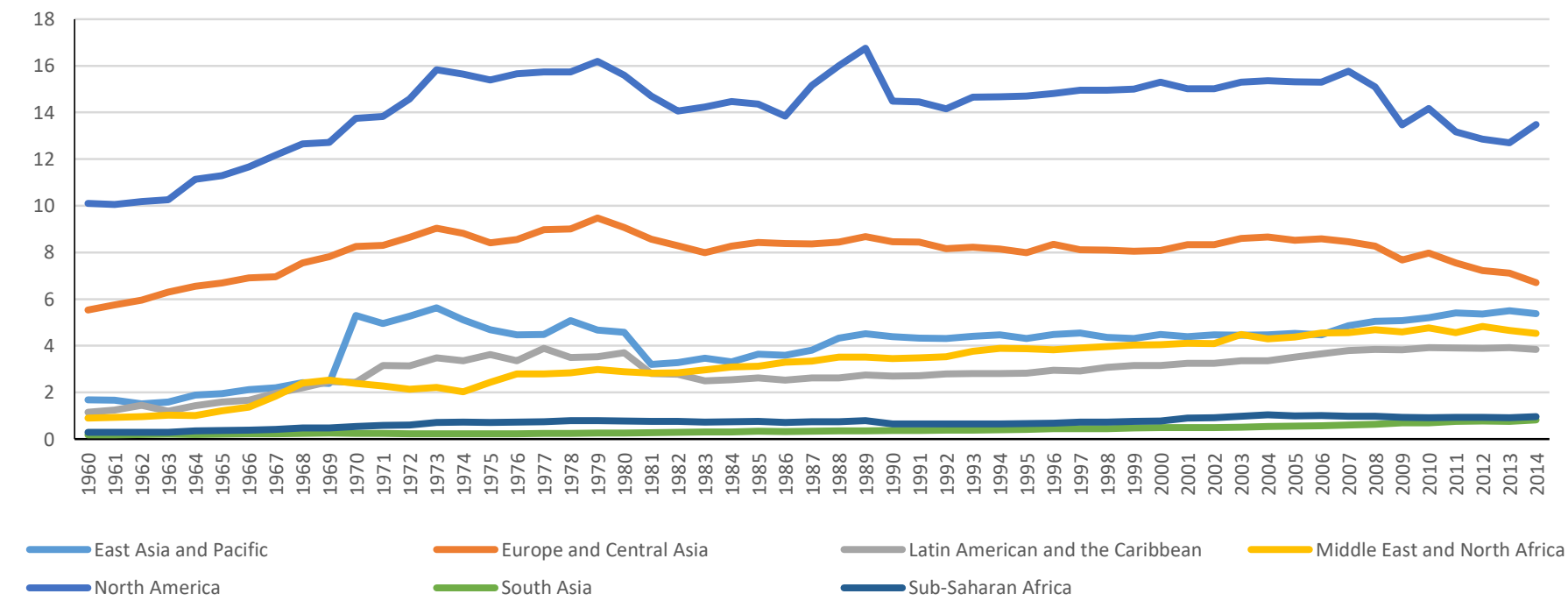

Source: World Bank, "Data Indicators," https://data.worldbank.org/indicator/en.atm.co2e.pc. 
Dr Muhammad Zubair Mumtaz \& Dr Zachary Alexander Smith

Figure 1 shows the level of $\mathrm{CO}_{2}$ emissions (metric tonnes per capita) around the globe during the period 1960 and 2014. To measure the level of $\mathrm{CO}_{2}$ emissions in these regions, this article uses the average of a metric tonne per capita among all countries. This figure illustrates that a higher magnitude of GHG would lead to a lower probability of protecting the environment. The amount of energy-related $\mathrm{CO}_{2}$ emissions per person depends on many parameters (e.g. energy mix, economic growth, efficiency, and personal patterns of energy consumption). Over the span of 55 years, North American countries (Bermuda, Canada, and the United States-US) have created a higher level of $\mathrm{CO}_{2}$ emission metric tonnes per capita which reflects the deterioration in the quality of the environment due to improper disposal of industrial wastage, non-fitness of vehicles, violation of procedures, and rule of law among other things. When examining Figure 1, we observe that Europe and Central Asia are second, however, it seems that environmental protection has decreased due to higher levels of $\mathrm{CO}_{2}$ emissions. Latin American \& the Caribbean, East Asia and Pacific, and the Middle East \& North African regions have a low level of $\mathrm{CO}_{2}$ emissions due to fewer production activities which reduces pollution. Lastly, South Asian and Sub-Saharan African countries have the lowest level of $\mathrm{CO}_{2}$ emissions per capita. To contend with envviornmelnal drgration, the concept of Green Finance was introduced which envisages that both public and private sectors should establish linkages between technological development, innovation, and the greening of the economy to explore untapped opportunities for economic growth. ${ }^{7}$ To achieve its objectives, it is imperative for both firms and governments to take appropriate measures for the imposition of relevant rules as well as disciplinary actions for non-compliance.

\footnotetext{
${ }^{7}$ City of London Corporation, Globalizing Green Finance: The UK as an International $\mathrm{Hub}$, report (London: City of London Corporation, 2016), greenfinanceinitiative.org/wpcontent/uploads/2016/11/Globalising-green-finance_AA3.pdf.
} 
Figure-2

Country-wise Position of $\mathrm{CO}_{2}$ Emissions (Metric Tonnes Per Capita) in South Asia

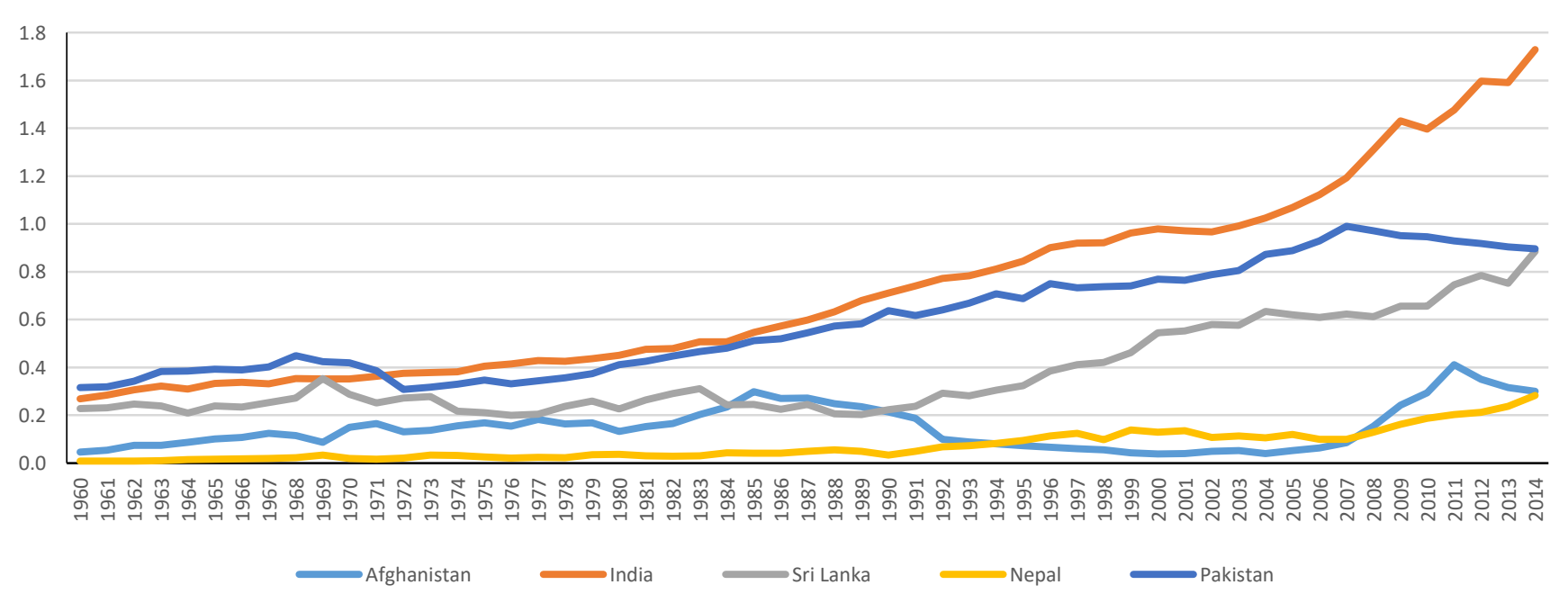

Source: World Bank, "Data Indicators,"

https://data. worldbank.org/indicator/EN.ATM.CO2E.KT?locations=8S.

IPRI JOURNAL • SUMMER 2019 


\section{Dr Muhammad Zubair Mumtaz \& Dr Zachary Alexander Smith}

To analyse the state of $\mathrm{CO}_{2}$ emissions metric tonnes per capita in South Asia, this study separately observes their impact on these countries. Figure 2 exhibits the magnitude of $\mathrm{CO}_{2}$ emissions in five countries which include Afghanistan, India, Nepal, Pakistan, and Sri Lanka during the period 1960 to 2014. Figure 2 illustrates that $\mathrm{CO}_{2}$ emissions per person increased which suggests that there is a direct relationship between the GHG emissions and population. In case of India, $\mathrm{CO}_{2}$ emissions per capita increased from 1.0 to 1.76 metric tonnes per capita between 2000 and 2014. Pakistan and Sri Lanka are ranked second and third. The results suggest that the governments of these countries should formulate and implement rules which require citizens to adhere to standards that improve the quality of the environment. The figure also presents the $\mathrm{CO}_{2}$ emission in Nepal and Afghanistan which indicate that these countries are facing a lower level of environmental and climatic issues. In general, procedural difficulties and the lack of awareness about how to safeguard the environment are major factors that may inflate the risks associated with environmental problems among countries located in the South Asian region as they pertain to $\mathrm{CO}_{2}$ emissions.

Considering the severity of environmental issues in different countries/ regions, a comprehensive strategy is required. The notion of Green Finance emphasises enhancing the financial industry's role in the reduction of hazardous environmental conditions by allocating funds to environmentally friendly firms, thus, achieving 'green' growth. The concept of Green Banking emerged in 2009 with establishment of the first Green Bank in Mt. Dora, Florida, USA. There is no straightforward definition of Green Finance. Subsequently, the banking industry formulated its green banking policies to promote Green Finance as well as Green Development.

The importance of Green Finance for developing countries has increased as the quality of their environment has deteriorated over time. ${ }^{8}$ Some researchers have reviewed green banking policies in countries like

\footnotetext{
${ }^{8}$ Kanak Tara, Saumya Singh, and Ritesh Kumar, "Green Banking for Environmental Management: A Paradigm Shift," Current World Environment 10, no. 3 (2015): 10291038, doi: 10.12944/CWE.10.3.36; and Tran Thi Thanh Tu and Tran Thi Hoang Yen, "Green Bank: International Experiences and Vietnam Perspectives," Asian Social Science 11, no. 28 (2015): 188-198, doi:10.5539/ass.v11n28p188.
} 
Bangladesh, China, India, Romania, Poland, and Vietnam to identify the potential possibilities in terms of a green economy and development. ${ }^{9}$

The State Bank of Pakistan (SBP) has introduced Green Banking Guidelines to promote environment-friendly activities by providing funds to different sectors of the economy. To follow directions of the SBP, all banks/development financial institutions (DFIs) are in the process of formulating procedures so that borrowers can be assessed before and after disbursement of funds to make sure that they meet the requisite standards set to achieve Green Finance reforms.

The purpose of this article is to examine the mechanism of Green Finance for sustainable development in Pakistan and developing countries, while evaluating the Green Banking Policy covering both the supply (banks/DFI) and demand side (borrowers). With regard to effective utilisation of Green Finance, both banks and borrowers should develop a broad understanding of green policies and recognise how this mechanism can be strengthened in the long run. Another objective of this study is to compare the Green Finance initiatives and policies in developing countries. It is found that China and India are far better at developing and implementing green banking policies which will help them to mitigate environmental issues. Pakistan's green banking policies are at a nascent stage as banks/DFIs are in the process of formulating them. Thus, it is going to take them time to benefit from these programmes.

\section{Green Finance - An Overview}

Green Finance is 'a key factor for achieving green growth which refers to balanced economic growth - an essential component to achieve sustainable growth. ${ }^{10}$ Another researcher argues that the 'driving power

9 Motoko Aizawa and Chaofei Yang, "Green Credit, Green Stimulus, Green Revolution? China's Mobilization of Banks for Environmental Clean-up," The Journal of Environment and Development 19, no. 2 (2010): 119-144, doi:

10.1177/1070496510371192; and Md. Ariful Islam, Salahuddin Yousuf, Kh. Fahim

Hossain and Md. Rayhan Islam, "Green Financing in Bangladesh: Challenges and

Opportunities - A Descriptive Approach," International Journal of Green Economics 8, no. 1 (2014): 74-91, doi:10.1504/ijge.2014.064469.

${ }^{10}$ Deokkyo Oh, "Current Status of Green Financing in Korea and Political Implications," Journal of Modern Accounting and Auditing 8, no. 9 (2012): 1358-1370, doi:10.17265/1548-6583/2012.09.011. 
of 'green' is to achieve patterns of economic growth by providing ecofriendly growth opportunities. ${ }^{11}$ The purpose of green growth is to improve a country's capability to manufacture goods in a way that overcomes environmental pollution, exploits green technology and knowledge, and expands energy and resources. According to the European Centre for the Development of Vocational Training, 'both public and private sectors are required to establish linkages between technological development, innovation and greening of the economy that provides untapped opportunities for economic growth. ${ }^{12}$ The effect of environmental innovation is positive for productivity and competitiveness which can act as a catalyst in reducing the cost to the economy and to achieve environmentally sustainable growth. ${ }^{13}$

In a recent study, the World Bank Group analysed green finance initiatives through a survey which covers the assessment of financing proposals, evaluation of actions taken to attract Green Finance, and environmental, social, and governance (ESG) risk management integration. ${ }^{14}$ The respondents broadly classified Green Finance on the basis of biosystem adaptation, energy efficiency, environmental protection measures, renewable energy, sustainable land management, recycling and waste management, and water efficiency.

To create the linkages between Green Finance and green growth, governments are required to promote and regulate green industrial markets by encouraging green technology, products and consumption. Green Finance is an important component of green growth through which firms

${ }^{11}$ Hee Jin Noh, Financial Strategy to Accelerate Innovation for Green Growth, report(Korea Capital Market Institute, 2010), https://www.oecd.org/sti/ind/45008807.pdf.

${ }^{12}$ ECDVT, Green Skills and Innovation for Inclusive Growth, report (Luxembourg: European Centre for the Development of Vocational Training, 2015), https://www.cedefop.europa.eu/files/3069_en.pdf.

${ }^{13}$ Cristina Martinez-Fernandez et al., "The Shrinking Mining City: Urban Dynamics and Contested Territory," International Journal of Urban and Regional Research 26, no. 2 (2012): 245-260, doi:10.1111/j.1468-2427.2011.01094.x.

${ }^{14}$ Aditi Maheshwari, Francisco Avendano and Peer Stein, "Measuring Progress in Green Finance - Findings from a Survey," http://unepinquiry.org/wpcontent/uploads/ 2016/09/5_Outline_Framework_for_Measuring_Progress_on_Green_Finance.p df. 
raise funds to explore their business ventures as well as introduce green technology. However, weak structures associated with Green Finance will not promote a green industry, as a result, green products will leave the market because the public will lose interest. This may cause economies to fail in 'going green' on a larger scale. To achieve objective of Green Finance, the financial industry is required to design new financial products, and then target industries and technologies for the requisite financing. These activities will lead to green growth by developing new technologies, promoting eco-friendly industries, and designing an efficient emissions trading scheme.

In January 2016, the Green Finance Initiative (GFI) was launched in London to create awareness regarding Green Finance and advocate for specific regulatory and policy plans that may help promote it globally. Only 122 out of a total of 1874 signatories for the Principles of Responsible Investment pledge, which represent asset owners, investment managers, and others, were from Asia, which indicates that the participation of Asian financial institutions in sustainable finance initiatives is still relatively low. ${ }^{15}$ The Green Finance Study Group identified obstacles from an institutional and market standpoint that confront Green Finance initiatives in developing countries. The study group emphasised institutional and market barriers within the financial system that limit sufficient mobilisation of private green investment in areas such as pollution control, clean energy, clean transportation, and energy-efficient products. ${ }^{16}$ The group also highlighted a few important areas which strengthen the entire process including:

- greening the banking system;

- greening the bond market;

${ }^{15}$ Ulrich Volz, "Fostering Green Finance for Sustainable Development in Asia," (paper 814, Asian Development Bank Institute, Tokyo, 2018), https://www.econstor.eu/bitstream/10419/190235/1/adbi-wp814.pdf.

${ }^{16}$ Mark Halle, Maya Forstater and Simon Zadek, Green Finance for Developing Countries - Needs, Concerns and Innovations, report (New York: United Nations Environment Programme, 2016), http://unepinquiry.org/wpcontent/uploads/2016/08/Green_Finance_for_Developing_Countries.pdf. 
- greening institutional investment;

- risk analysis; and,

- measuring progress.

Presently, banks in most developing countries lack the capacity to evaluate borrowers and the absence of 'green' performance measurement appears to be a constraint. The development of innovative products (e.g. green bonds) is another barrier for developing economies. Lack of a clear and comparable explanation could shake the trust of investors, whereas, uncertainty and high cost may also create concerns in terms of issuance. The other constraint refers to a lack of disclosure conditions and poor Environmental Impact Assessment (EIA) capacity that may preclude full incorporation of material factors into the investment decision-making process. Banks/DFIs of developing countries may also avoid the effective inclusion of environmental risks into financial decision-making processes.

\section{Mechanism of Green Finance for Sustainable Development in Pakistan}

This section first highlights the environmental and climate issues in Pakistan, and then discusses the Green Finance policies proposed by the SBP covering both the supply and demand side aspects.

\section{Environmental and Climate Issues in Pakistan}

Pakistan is facing many environmental challenges which pose severe threats to human health and life. According to a report, energy (with 51 per cent share) and agriculture-livestock sectors are the major sources of GHG emissions in the country. Analysis suggests that climate finance is an important factor which will shift industries towards low carbon mitigation strategies. Therefore, financing instruments are required for promoting climate finance in the country. ${ }^{17}$

${ }^{17}$ Malik Amin Aslam Khan, "National Economic \& Environmental Development Study (NEEDS) Pakistan," (report, New York: United Nations Framework Convention on Climate Change, 2011),

https://unfccc.int/files/adaptation/application/pdf/pakistanneeds.pdf. 
A prior study examined the relationship between per capita carbon emissions, income, energy consumption, and foreign trade in Pakistan during the 1972 to 2008 period, and illustrated a quadratic long run relationship between carbon emissions and income. Furthermore, it found that per capita carbon emissions and foreign trade led towards increase in emissions in the country. ${ }^{18}$ In another study, researchers investigated the co-integrating relationship between carbon emissions, energy consumption, trade openness, and financial development in Pakistan during the period 1971 to 2011. They found an inverted U-shaped association between carbon emissions and energy consumption with a benchmark of energy consumption per capita at $640 \mathrm{~kg}$ of oil equivalent. They also reported that at present, the economy is functioning at less than this level, and it is likely that carbon emissions will slowly increase over some time until the benchmark level is reached. ${ }^{19}$

To determine the issues related to $\mathrm{CO}_{2}$ emissions, Chang identified surplus or slack $\mathrm{CO}_{2}$ emissions of a single country. He adjusted $\mathrm{CO}_{2}$ emission of each country for international trade to constitute $\mathrm{CO}_{2}$ outsourcing and carbon appropriation through forest products to ascertain their net $\mathrm{CO}_{2}$ emissions. He reported that countries with more and less than average net per capita $\mathrm{CO}_{2}$ emissions have surplus and slack emissions, respectively. ${ }^{20}$

Pakistan has been declared among the top ten countries which is most influenced by climate change. ${ }^{21}$ Climate change inversely affects health, agriculture, and overall economic activities of the country. The primary factors include $\mathrm{CO}_{2}$ emissions, population explosion, deforestation, and the lack of resources to mitigate and adapt to climate change effects. Water scarcity is another problem that exists in the country

${ }^{18}$ Muhammad Nasir and Faiz ur Rehman, "Environmental Kuznets Curve for Carbon Emissions in Pakistan: An Empirical Investigation,” Energy Policy 39, no. 3 (2011): 1857-1864, doi: 10.1016/j.enpol.2011.01.025.

${ }^{19}$ Syed Jawad Hussain Shahzad, Ronald Ravinesh Kumar, Muhammad Zakaria and Maryam Hurr, "Carbon Emission, Energy Consumption, Trade Openness and Financial Development in Pakistan: A Revisit," Renewable and Sustainable Energy Reviews 70 (2017): 185-192, doi:10.1016/j.rser.2016.11.042.

${ }^{20}$ Sun Joseph Chang, "Solving the Problem of Carbon Dioxide Emissions," Forest Policy and Economics 35 (2013): 92-97, http://dx.doi.org/10.1016/j.forpol.2013.06.013.

${ }^{21}$ Ibid. 
due to climate change, lack of sufficient reservoirs to hoard water, and traditional irrigation systems. The environment in Pakistan is also affected by air pollution. This is due to the emission of toxic gases from industries, brick kilns, and the release of carbon from transport vehicles. Waste management is another important concern. Industrial firms and hospitals dispose of their waste in the ocean, lakes, and rivers which is hazardous for aquatic and human life dependent on these water resources. These problems arise because there are improper mechanisms to dispose of waste.

\section{Green Finance Policies in Pakistan}

In line with international policies, the SBP devised a framework for introducing green banking to Pakistan in 2017 which seeks:

To reduce vulnerability of banks/ development finance institutions (DFIs) from risk arising from the environment, fulfill their responsibilities for the protection of environment and provide finance to transform the economy into a resource efficient and climate resilient one. ${ }^{22}$

Recently, the International Finance Corporation (IFC) signed an advisory agreement with the SBP to support green banking in Pakistan which is a part of IFC's obligation to help countries' transition to green, low carbon, and sustainable economies. ${ }^{23}$ In this context, the IFC will provide support to improve environmental risk management practices, and ensure ethical lending practices.

To circumvent environmental issues, banking guidelines mainly focuses on risk management processes created to measure, evaluate, and examine environmental risks that can be generated from business

${ }^{22}$ Green Banking Guidelines, ( State Bank of Pakistan, 2017), http://www.sbp.org.pk/smefd/circulars/2017/C8-Annex.pdf.

23 "WB to Support Green Banking in Pakistan," Dawn, August 31, 2018, https://www.dawn.com/news/1430071. 
activities once banks disburse funds. ${ }^{24}$ Environmental risks of the financing portfolio of banks/DFIs are those that are initiated by the transactions of their borrowers. These risks may instantly affect production-related activities and the environment in the long run. This generates uncertainties and partial or full losses in a banks/DFIs revenues. The purpose of introducing Green Finance is to ensure that an Environmental Risk Management System (ERMS) is followed by banks/DFIs which may help to minimise environmental risks. This system generally covers identification of risk parameters, factors causing risks, evaluation of potential risk consequences, and the consideration of risk minimisation factors. Their brief description is presented in ensuing paragraphs.

\section{Environmental Due Diligence}

Environmental due diligence is an organised process used to evaluate environmental consequences and their impact on the credit quality of a respective financing transaction at the stage of first assessment, and to provide successive reviews of performance and creditworthiness of the borrower. This process evaluates the adherence to environmental regulations which are applicable to the prospective borrower.

The Pakistan Environmental Protection Act of 1997 upholds environmental protections. ${ }^{25}$ The clauses in the Protection Act clearly stipulate that every project requires an initial environmental examination which ensures that the new development does not damage natural resources, including freshwater. ${ }^{26}$ Under this Act, the Environmental Protection Agency (EPA) was established to formulate rules, regulations, standards, and guidelines to protect the environment. The objective of this process is to identify the factors that can overcome adverse impacts to the

\footnotetext{
${ }^{24}$ Ibid.

${ }^{25}$ GoP "Pakistan Environmental Protection Act," 1997, Government of Pakistan, http://www.na.gov.pk/uploads/documents/Pakistan=Environmental-Protection-Act1997.pdf.

${ }^{26}$ IUCN, "Environment Law in Pakistan- Governing Natural Resources and the Processes Institutions that Affect Them," report (Karachi: World Conservation Union, 2005), https://cmsdata.iucn.org/downloads/pk_envlaw_fed_vol_1.pdf.
} 
environment after considering a Cost and Benefit Analysis (CBA) for applying environmental resources in the proposed projects.

To study environmental compliance in the textile industry of Pakistan, researchers surveyed 60 large and medium textile processing units using the stratified random sampling technique. With regard to following environmental regulations, they reported that 87 per cent firms adopted more than two environmental management practices; 50 per cent more than five practices; and 12 per cent employed the entire nine regulations. They also found that large firms followed different environmental practices when compared with medium firms to fulfill international standards. ${ }^{27}$

The due diligence process determines the environmental risk parameters and also investigates the seriousness associated with the risks as well as chances of potentially hazardous outcomes. The determination of environmental factors provides provisions to establish a framework to develop some standard questions in a way that address any environmental risk that may be inherent in the usage of loan proceeds.

\section{Environmental Risk Rating}

With regards to environmental risk ratings, assessment of environmental parameters includes severity, scope, duration, and compliance with legal requirements; therefore, the banks/DFI may evaluate the possibilities of occurrence of harmful events to the environment. It is also imperative that both qualitative and quantitative methods are used to gauge the magnitude and likelihood of the consequences associated with these environmental risks. The environmental risk rating associated with these individual characteristics may be merged together with the terms of financing, types and sizes of customers and specific sector to create more thoughtful green financing options. Consequently, banks/DFIs may apply a statistical

${ }^{27}$ Ghulam Samad, Waseem Gulzar and Vaqar Ahmed, "Environmental Regulations and Compliance in the Textile

Processing Sector in Pakistan: Empirical Evidence," (paper, South Asian Network for Development and Environmental Economics, Nepal, 2015),

https://www.researchgate.net/publication/281976309_Environmental_Regulations_and Compliance_of_Textile_Processing_Sector_of_Pakistan_Empirical_Evidence. 
approach to reach a sole uniform rating of the financing proposal. Table 1 exhibits the relationship between environmental due diligence and risk rating.

Table-1

\section{Relationship between Environmental Due Diligence \& Risk Rating}

\begin{tabular}{|c|c|}
\hline Due Diligence & Risk Rating \\
\hline $\begin{array}{l}\text { - To comply with environmental } \\
\text { regulations } \\
\text { - To follow sector-specific criteria } \\
\text { - To conduct non-technical due } \\
\text { diligence }\end{array}$ & $\begin{array}{l}\text { - Findings of due diligence formulate } \\
\text { risk rating } \\
\text { - To identify risks at various level } \\
\text { - Consequences of risk rating }\end{array}$ \\
\hline
\end{tabular}

Source: SBP, "Green Banking Guidelines," State Bank of Pakistan (2017), http://www.sbp.org.pk/smefd/circulars/2017/C8-Annex.pdf.

The process associated with due diligence and risk rating provides assistance to banks/DFIs to monitor, minimise, and control environmental risks through credit decision-making processes, environmental improvement plans, and environmental risk provisions in financing agreements with the borrowers. Questions arise in terms of how this mechanism supports the entire process. To systematise the credit approval processes, banks/DFIs may develop an escalation matrix which provides different layers for analysing the credit exposures and environmental risks associated with the respective financing.

Keeping in view the severity of environmental risk, they may negotiate with the borrower on a time-bound Environmental Improvement Plan (EIP) indicating necessary actions and measures for implementation by the borrower as a pre-condition for the approval of financing. The objective of EIP is to minimise the risk associated with a transaction as well as arrive at an acceptable level for financing. There may be a possibility that the environmental risk of a borrower may be altered, after the approval of financing, due to change in the business structure, 
operations, or change in requirements of applicable environmental laws. The banks/DFIs should agree on regular reviews with the borrower for a rational declaration of continuing compliance in line with environmental indicators.

The application of a borrower is independently reviewed by the corporate finance department, which considers the appropriate due diligence and risk rating measures. The legal department also ensures that a loan agreement is signed with the borrowers, and describes the level of environmental safeguards in the condition precedent and covenants. To monitor the financing activities, a regular review is required to identify whether the borrower is obligated to follow the terms and conditions under financing contracts.

\section{Facilitation under Green Banking}

Green banking is a systematic technique of environmental risk management which provides a provision for banks/DFIs to introduce new products and markets like energy efficiency, carbon markets, and green mortgages, etc. A well-defined structure of financing facilities for environmental projects will help banks to develop an image of the environmentally cognizant firms, and also facilitate developing conducive relationships.

The banks/DFIs act as a catalyst for economic activities through financing facilities and advisory services to their borrowers. It is imperative for banks to arrange discussions with business houses or potential borrowers, whereby, the banks emphasise promoting Green Finance products. They serve as powerful agents of change for steering businesses to more sustainable and environmentally friendly strategies, and operations through reasonable allocation of financial resources. In short, green banking facilitation should be developed as a profitable business proposition with sufficiently large business potential. 


\section{Supply Side of Green Finance}

With the advent of Green Finance in Pakistan, banks/DFIs are responsible for providing funds after necessary approval of borrowers. The principles of green banking initiate the due diligence process for the borrowers which will subsequently assign an overall risk rating. Upon approval from the credit department, funds are disbursed. Alternatively, provisions need to be added in the financing agreement wherein the borrowers are liable to fulfill the conditions, and the credit department will review the process on a periodic basis.

Figure 3 demonstrates the process of evaluating the environmental risk of borrowers. In general, the financing associated with a project is monitored on regular basis, however, the conditions to evaluate environmental risk are tricky because banks/DFIs are required to appoint specialised personnel to provide consolidated feedback on the development of the financing projects. Thus, banks/DFIs should identify the specific criteria to be applied in the monitoring process on which borrowers are evaluated. Projects are segregated on the basis of small- or large-sized, however, it would be difficult for banks to comprehend the environmental issues for multiple projects; so, external specialists are required to assess the probability of violating environmental laws on the part of the borrowers which ultimately increases the cost of the transaction. This increase in cost compels banks to avoid the risks associated with assessment, therefore, SBP should impose such a mechanism which should be enforced in all respects to evaluate the borrowers' business activities. 
Dr Muhammad Zubair Mumtaz \& Dr Zachary Alexander Smith

Figure-3

Process of Evaluating the Borrower under Green Finance

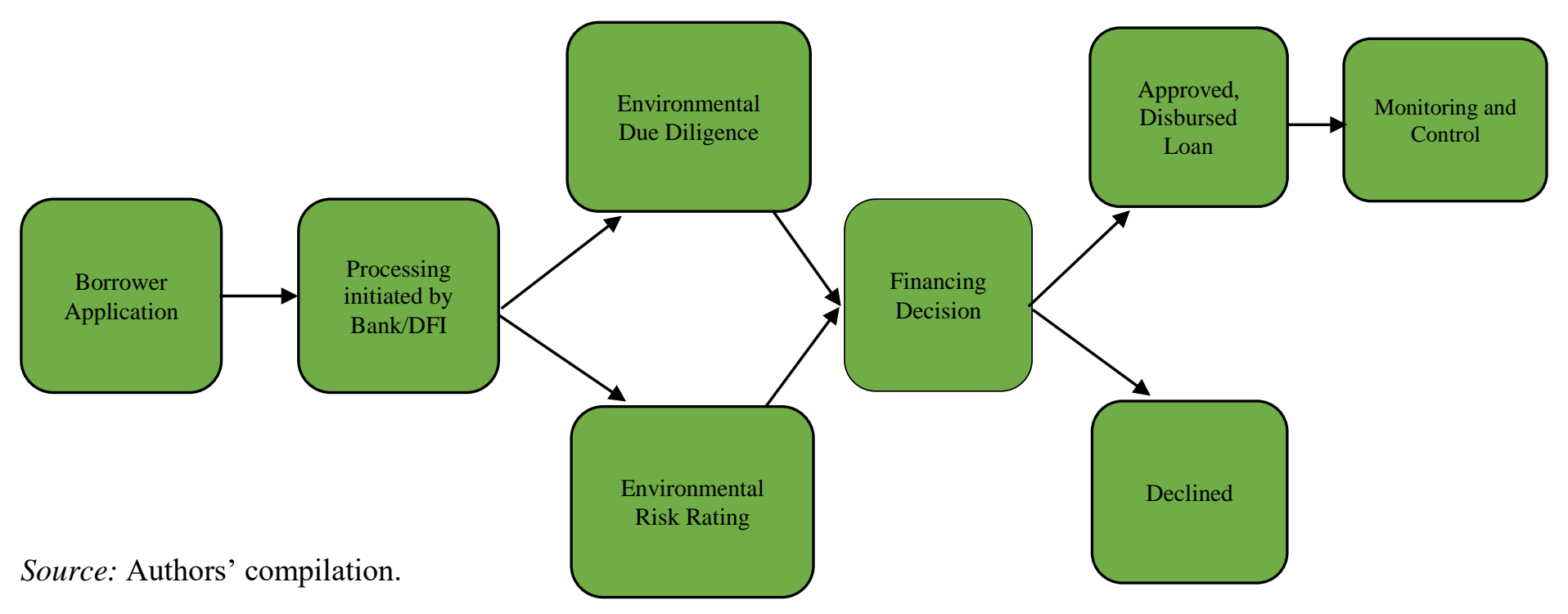


In order to strengthen the process, the Board of Directors of banks/DFIs develop Green Finance policies within their respective institutions. The maximum exposure limits may also be set for those industries which are more hazardous to the environment. Moreover, the Board of Directors should review and approve Green Finance strategies. To implement green banking, management should assign an official to supervise and review the activities associated. It is important to note that the green banking officer should be well versed in environmental risk assessment and monitoring, green product development, and operational improvement measures to reduce resource consumption. The risk management department of the bank/DFI should be liable for regular reporting with regard to inherent environmental risk in the banks/DFIs portfolio, and compliance of business lines with relevant environmental regulations. Apparently, the skills required to oversee this process and identify the environmental issues are non-existent in the market place. All banks/DFIs should train their employees to develop their expertise considering due diligence and environmental risk assessment so that they are helpful in identifying the riskiness of borrowers and deciding whether the loan can be granted or otherwise.

It is difficult for banks to comply and provide environmentally risk-free Green Finance. Business dynamics may change over time. In a particular situation, a question may arise as to how all the banks might take necessary steps to overcome environmental risks over the long horizon of Green Finance. Although, SBP is fully cognizant of this fact, applying Green Finance guidelines in all banks/DFIs will eventually help to improve environmental conditions. However, strict and regular monitoring is required to oversee the projects of the borrowers so they are not violating the rules of Green Finance.

There is a need to build capacity in and develop guidelines for issuing green bonds which allow for and encourages banks and enterprises to float them. This possibility of raising funds will promote Green Finance in Pakistan. The Securities \& Exchange Commission of Pakistan (SECP) is also required to formulate a mechanism for firms which help to issue green initial public offerings (IPOs). These IPOs will improve the framework through which environmental performance is communicated and recognised in equity markets. Along similar lines, the government 
may introduce a scheme of green funds which will promote the development of green industry funds through Public-Private Partnership (PPPs) arrangements. It is important that the government should intervene in developing policies for green bonds, green IPOs, and green funds which will help the concerned bodies to take necessary measures as well as build confidence on the part of firms and investors.

Another objective of Green Finance is to introduce 'green technology' which may help to apprehend environmental issues. Critically speaking, it is practically impossible that all firms will follow the procedures and apply the theme of green technology. Green Finance emphasises that every firm should follow environmental conditions. If a bank decides not to provide a loan to a borrower due to non-compliance of environmental procedures, the same borrower may go to another bank which is not strictly applying the preconditions of financing. With regard to the banking industry, public, private, and foreign banks exist in Pakistan and their objective is to provide funds based on whether a borrower is fulfilling the requirement to get financing or not. The SBP should adopt procedures that can be applied in a true spirit across the board so 'no client effect' exists.

Second, it is also important that the SBP should issue directives in terms of evaluating the borrowers in a clear and concise manner, which is applicable to all banks/DFIs.

Third, there is no mechanism defined that illustrates how to proceed with regard to the proposed litigation cases. There should be a dispute settlement body which can review the petition, and then take necessary measures to arbitrate any disputes.

Fourth, obtaining Green Finance to bring green growth in the country is difficult to achieve, not only in Pakistan but in all developing countries. Since it is difficult for banks/DFIs and borrowers to follow the rules, this raises a concern in terms of how it can be implemented and overviewed by regulators. Lastly, a huge cost is associated with training employees in the banks/DFIs so they can be equipped with tools to evaluate prospective borrowers. 


\section{Demand Side of Green Finance}

To expand business activities, financing is a prerequisite for green firms which helps them to obtain land, buildings, plants, machines, and equipment. As per the Green Banking Policy, firms are required to maintain their business activities by complying with the procedures set under the environmental laws.

The first problem this study foresees is their difficulty to meet the procedures owing to different sizes of firms. Under this policy, it seems that small firms may not be able to borrow funds to generate or expand their business activities.

Second, firms lack information as to how to apply the environmental measures so they are not violating business rules. The Green Finance Policy is hardly two years old, and it is important that SBP educate relevant stakeholders to ensure that procedures are followed.

Third, a temporary phase of implementing rules should be announced by the SBP so that firms can prepare themselves to meet these challenges. This study suggests that this phase should span a period of at least two years so that firms can have enough time to fulfill the necessary conditions for getting funds from banks/DFIs.

Fourth, the entire procedure of Green Finance focuses on the reduction of GHG emissions, but the policy is silent on how to reduce $\mathrm{CO}_{2}$ emission by firms. This implies that $\mathrm{CO}_{2}$ emissions can be reduced in a phased manner or full coverage is required. These things should be highlighted by the SBP so that all aspects can be cleared and implemented to improve the environment of the country.

Last but not least, banks/DFIs are also required to train their personnel so that they have some specific knowledge by which they are able to monitor their projects/firms and to determine whether these firms are satisfying the rules and regulations. In case of any deficiency, they can guide clients to take necessary actions to overcome the relevant issues.

Practically speaking, it is not easy for firms to comply with these regulations. There should be a mechanism that can be developed for firms so that contents of the Green Finance Policy can be implemented. To evaluate a borrower, banks/DFIs apply an environmental due diligence and risk rating system, the application cannot be processed if they are 
Dr Muhammad Zubair Mumtaz \& Dr Zachary Alexander Smith

unsatisfied which indicates that the borrower is not fully aware of how to apply and comply with the rules. In this regard, SBP should conduct workshops at the sectoral associations and Chambers of Commerce \& Industry level so that the concerned firms could learn about the policies which in turn will achieve the objectives of the State Bank. This may also help to bridge the gap by disseminating information to both banks and prospective borrowers.

\section{Overview of Green Finance Mechanism in Developing Countries}

In many countries, the concept of green banking has been introduced in recent years, particularly developing countries, because the conditions of environmental protection are traded off to obtain economic growth and development. After the Global Financial Crisis in 2008, all countries felt the need to modernise their financial systems which may help them to withstand losses. To address the issue of sustainable development, the area of Green Finance has emerged as a role model for the prospects of banking which establishes the relationship of a green economy to sustainable development.

This section reviews and compares the Green Finance policies among developing countries. China was the first to lead and contribute to Green Finance. In the initial stage (2007-10), China formulated 'green credit policies' to encourage banks to provide financing for renewable projects which are environmental friendly. The first kind of green policy established the foundation to achieve sustainable banking in the country. In the consolidation stage (2011-14), various efforts were made to frame green finance guidelines and credit information systems. Thereafter, the China Banking Regulatory Commission issued a directive for the accountability of green credit with a provision to disclose green credit information. In the implementation phase (2015 until now), most research proposals in terms of Green Finance were approved. The Green Finance Committee of the China Society for Finance and Banking was formed along with other competent institutions to promote Green Finance by meeting requisite standards, developing evaluation mechanisms and environmental risk analysis, and capacity building and training. 
Many researchers have highlighted the importance and significance of green finance in India. They argued that Green Finance is promoting environmental friendly practices and reducing the carbon footprint from banking activities. ${ }^{28}$ In 2010, the State Bank of India took an initiative to launch a Green Channel which helped to promote green business activities. On the directives of the State Bank, terms and conditions with regard to environmental risks have been added to the banking policies for evaluating potential borrowers, and considering whether they meet environmental-related activities or otherwise. On the positive front, green bonds have been issued to support green energy in India since 2015. In nutshell, banks/DFIs are taking appropriate measures to incorporate all the conditions for assessing lending transactions, however, a lot of effort is still required to fully implement their green policy initiatives.

${ }^{28}$ Bibhu Prasad Sahoo, Amandeep Singh, and Neeraj Jain, "Green Banking in India: Problems and Prospects," International Journal of Research - Granthaalayah 4, no. 8 (2016): 92-99, doi: 10.5281/zenodo.61169. 
Dr Muhammad Zubair Mumtaz \& Dr Zachary Alexander Smith

Table-2

\section{Comparison of Green Finance Policies in Developing Countries}

\begin{tabular}{|c|c|c|c|}
\hline Country & Guidelines & Approach & Development \\
\hline Bangladesh $^{29}$ & 2011 & $\begin{array}{l}\text { Implemented a comprehensive green finance policy to } \\
\text { safeguard environmental degradation and ensure sustainable } \\
\text { banking practices. Banks have included environmental and } \\
\text { climate change risk as part of existing risk methodology to } \\
\text { assess a potential borrower. They are also setting up green } \\
\text { branches which is an integral part of the green policy. }\end{array}$ & $\begin{array}{l}\text { The policy was divided into three phases. In phase I, } \\
\text { banks/DFIs have to develop green banking policy. Phase II } \\
\text { suggests formulating sector-specific environmental policies, } \\
\text { green strategic planning, setting up green banks and improvec } \\
\text { in-house environmental management. In phase III, } \\
\text { banks/DFIs are expected to address the entire ecosystem by } \\
\text { assessing environmentally friendly initiatives and introducing } \\
\text { innovative products. The time frame to apply the above } \\
\text { phases has lapsed, however, banks/DFIs are in different } \\
\text { phases to comply with these rules. }\end{array}$ \\
\hline Brazil $^{30}$ & 2014 & $\begin{array}{l}\text { The Central Bank of Brazil passed a mandatory resolution on } \\
\text { social and environmental responsibility for financial } \\
\text { institutions. Banks are required to engage in E\&S stress } \\
\text { testing and include E\&S into capital requirements in line } \\
\text { with the Internal Capital Adequacy Assessment Process. } \\
\text { Banco do Brazil also formulated a general framework for } \\
\text { types of risks that should be included. }\end{array}$ & $\begin{array}{l}\text { Detailed guidelines exist for the implementation of the socio- } \\
\text { environmental responsibility policy by all financial } \\
\text { institutions authorised to operate by the central bank. Most of } \\
\text { the banks are now including E\&S risk into their reporting and } \\
\text { risk management strategies. }\end{array}$ \\
\hline
\end{tabular}

29 “Policy Guidance for Green Banking," (Banking Regulation \& Policy Department, Dhaka, 2011),

https://www.bb.org.bd/mediaroom/circulars/brpd/feb272011brpd02e.pdf.

${ }^{30}$ Guru Prasad Rao, Sandeep S. Shenoy, C. K. Hebbar, and Niranjan J. Prabhu, "BRICS Banking: Review of Green Banking Initiatives among the BRICS

Nations," The Business and Management Review 9, no. 1 (2017): 44-51. 
Green Finance for Sustainable Development in Pakistan

\begin{tabular}{|c|c|c|c|}
\hline China $^{31}$ & 2007 & $\begin{array}{l}\text { China's green credit policy laid the foundation for } \\
\text { sustainable banking. In 2009, China Banking Association } \\
\text { took environmental responsibility in supporting national } \\
\text { industrial and environmental policies. Afterward, China } \\
\text { Banking Regulatory Commission described the } \\
\text { responsibilities and accountability of bank's management in } \\
\text { green credit, which requires full disclosure of green credit } \\
\text { information. }\end{array}$ & $\begin{array}{l}\text { In an initial phase (2007-10), China formulated credit policy } \\
\text { for green financing. In the consolidation phase (2011-14), it } \\
\text { established green financing policies and green credit } \\
\text { information systems. In the implementation phase ( } 2015 \text { till } \\
\text { now), the country has been putting a lot of efforts in R\&D, } \\
\text { green finance standards, and environmental risk analysis. }\end{array}$ \\
\hline Egypt $^{32}$ & 2014 & $\begin{array}{l}\text { The Federation of Egyptian Banks is focusing to consolidate } \\
\text { its institutional approach towards sustainability and to } \\
\text { support the efforts of comprehensive development in } \\
\text { economic, social and environmental levels. Subsequently, a } \\
\text { Commission has been established to oversee adherence to the } \\
\text { best international practices. }\end{array}$ & $\begin{array}{l}\text { To achieve the purpose of green finance, Egyptian banks are } \\
\text { presently transforming their banking policies so that ESG } \\
\text { objectives can be achieved. }\end{array}$ \\
\hline India $^{33}$ & 2010 & $\begin{array}{l}\text { The State Bank of India introduced the Green Channel as an } \\
\text { initial step of green banking. The State Bank included terms } \\
\text { of environmental risks for assessing the borrowers. Banks are } \\
\text { generally following industry-led voluntary green lending } \\
\text { guidelines. An important milestone is that green bonds were } \\
\text { issued to support green energy in } 2015 \text {. }\end{array}$ & $\begin{array}{l}\text { As per the directives of the State Bank of India, banks/DFIs } \\
\text { have taken necessary measures for green banking in terms of } \\
\text { policies as well as the branch banking. However, a lot more } \\
\text { efforts are required to make this process rigorous. }\end{array}$ \\
\hline
\end{tabular}

${ }^{31}$ Yunwen Bai, Michael Faure, and Jing Liu, “The Role of China's Banking Sector in Proving Green Finance,” Duke Environmental Law \& Policy Forum 24, no. 89 (2013): 89-140, https://scholarship.law.duke.edu/cgi/viewcontent.cgi?article=1254\&context=delpf.

${ }^{32}$ Hossam Mounir, "Egyptian Banks Find their Way Towards Green Banking as Path to Sustainable Development," Daily News Egypt, October 25, 2018, https://dailynewsegypt.com/2018/10/25/egyptian-banks-find-their-way-towards-green-banking-as-path-to-sustainable-development/.

${ }^{33}$ Suresh Chandra Bihari and Bhavna Pandy, "Green Banking in India," Journal of Economics and International Finance 9, no. 1 (2015): 1-17, doi: 10.5897/JEIF2014.0599.

IPRI JOURNAL — SUMMER 2019 
Dr Muhammad Zubair Mumtaz \& Dr Zachary Alexander Smith

\begin{tabular}{|c|c|c|c|}
\hline Indonesia $^{34}$ & 2014 & $\begin{array}{l}\text { Developed a roadmap for sustainable finance (2015-19) } \\
\text { which illustrates the detailed description of green lending. } \\
\text { Bank Indonesia and Otoritas Jasa Keuangan have engaged in } \\
\text { organising capacity building, working on environmental \& } \\
\text { social risk and green lending with the financing sector. }\end{array}$ & $\begin{array}{l}\text { With regard to development, commercial banks are not } \\
\text { properly engaging in environmental and social risk or green } \\
\text { lending. In terms of mandatory requirements, banks are } \\
\text { required to apply them properly and make progress. }\end{array}$ \\
\hline Mongolia $^{35}$ & 2014 & $\begin{array}{l}\text { The approach emphasizes on achieving sustainable finance } \\
\text { by striving to avoid or mitigate negative environmental and } \\
\text { social effects which contribute towards diversification of the } \\
\text { economy by obtaining green economic growth. }\end{array}$ & $\begin{array}{l}\text { The banking principles and sector guidelines were effectively } \\
\text { placed on January } 1,2015 \text {, and based on eight principles for } \\
\text { protecting: natural environment, people \& communities, } \\
\text { cultural heritage, green economic growth, financial inclusion, } \\
\text { ethical finance \& corporate governance, transparency \& } \\
\text { accountability and reporting. }\end{array}$ \\
\hline Nepal $^{36}$ & 2012 & $\begin{array}{l}\text { Nepal Rastra Bank set up an association to support the } \\
\text { development of environmental and social risk management } \\
\text { by banks/DFIs to provide green lending. }\end{array}$ & $\begin{array}{l}\text { Banks/DFIs did not put efforts to promote green finance. } \\
\text { Regulators are required to follow strict measures for the } \\
\text { adherence of procedures set under green banking policies. }\end{array}$ \\
\hline Nigeria $^{37}$ & 2012 & $\begin{array}{l}\text { The guidelines relating to sustainable banking were followed } \\
\text { which include nine parameters covering the implementation } \\
\text { of significant and transparent ESG practices. On annual } \\
\text { basis, banks/DFIs identify the percentage of their portfolio } \\
\text { assessed which shows the outcomes for the borrower and the } \\
\text { bank. }\end{array}$ & $\begin{array}{l}\text { In March 2018, FMDQ OTC Securities Exchange, Climate } \\
\text { Bonds Initiatives (CBI), and Financial Sector Deepening } \\
\text { Africa formed a partnership to strengthen financial stability } \\
\text { and support overall economic growth and also issued } \\
\text { Nigerian green bonds for a period of three years. This } \\
\text { initiative may help to promote green banking in Nigeria. }\end{array}$ \\
\hline
\end{tabular}

${ }^{34}$ Simon Dikau and Josh Ryan- Collins, "Green Central Banking in Emerging Market and Developing Country Economies," The New Economics Foundation, https://neweconomics.org/uploads/files/Green-Central-Banking.pdf.

35 "Mongolian Sustainable Finance" (2014), https://www.ifc.org/wps/wcm/connect/05296e6c-86e0-4475-ae0e-20200dca900b/MBA_Principles-and-GuidanceNotes-Mongolia_Final.pdf?MOD=AJPERES\&CVID=kKZr0cX.

${ }^{36}$ Bhubanesh Pant, "Promoting Green Finance: Sustainable Development," The Himalayan Times, August 15, 2017,

https://thehimalayantimes.com/opinion/promoting-green-finance-sustainable-development/.

${ }^{37}$ GoN, "Exposure Draft of the Reporting Template for the Nigeria Sustainable Banking Principles," Central Bank of Nigeria (2013),

https://www.cbn.gov.ng/out/2013/fprd/exposure\%20draft\%20of\%20the\%20reporting\%20template.pdf. 
Green Finance for Sustainable Development in Pakistan

\begin{tabular}{|c|c|c|c|}
\hline Pakistan $^{38}$ & 2017 & $\begin{array}{l}\text { The SBP introduced green banking guidelines to promote } \\
\text { green finance in the country. }\end{array}$ & $\begin{array}{l}\text { Banks/DFIs are in process of formulating green banking } \\
\text { policies to be implemented for promoting sustainable } \\
\text { banking. }\end{array}$ \\
\hline Peru $^{39}$ & 2015 & $\begin{array}{l}\text { Banking, Insurance and Private Pension Fund Administrators } \\
\text { launched the regulation for social and environmental risk } \\
\text { management. Also, strengthen the role of due diligence in the } \\
\text { regulation of socio-environmental risk management for } \\
\text { financial firms. }\end{array}$ & $\begin{array}{l}\text { Banking groups are developing these terms and conditions } \\
\text { into banking policies so as to evaluate the borrowers. }\end{array}$ \\
\hline Vietnam $^{40}$ & 2015 & $\begin{array}{l}\text { Formulated an action plan for the banking sector to apply the } \\
\text { National Strategy on green growth by } 2020 \text {. The State Bank } \\
\text { of Vietnam has set many priorities to promote green finance. }\end{array}$ & $\begin{array}{l}\text { Banks are exploring green finance opportunities at different } \\
\text { levels. However, the State Bank has issued directives to } \\
\text { formulate ESG measures to evaluate borrowers. }\end{array}$ \\
\hline
\end{tabular}

Source: Authors' compilation.

${ }^{38}$ Ibid.
${ }^{39}$ Ibid.
40 “Ahead in Green Lending," Vietnam Economic Times, May 20, 2018, http://vneconomictimes.com/article/op-eds/ahead-in-green-lending.

IPRI JOURNAL • SUMMER 2019 


\section{Dr Muhammad Zubair Mumtaz \& Dr Zachary Alexander Smith}

While reviewing the case of Bangladesh, it is found that Green Finance policy and strategy framework have been developed and applied in three phases. ${ }^{41}$ Firstly, banks/DFIs are required to formulate their green policies including policy formulation and governance, initiation of environmental risk to avoid default risk, the creation of a climate risk fund, training of employees, providing awareness to consumers, and disclosing green finance activities. ${ }^{42}$ Secondly, banks/DFIs broaden their horizon which covers the formulation of sector-specific environmental policies, green strategic planning, environmental risk management plan from the perspective of financial institutions, and rigorous training to educate clients and business houses. Thirdly, banks/DFIs design and introduce new products, report on green banking practices, and the environment-friendly corporate social responsibility.

The Nigerian Sustainable Banking Principles was applied in 2012. According to Central Bank of Nigeria news release, 'the adoption of the principles is to deliver positive development which impacts to the society while protecting the communities and environment in which financial institutions and borrowers operate. ${ }^{43}$ Overall, these principles consist of environmental and social (E\&S) risk management, E\&S footprint, human rights, financial inclusion, governance, capacity building, collaborative partnership, and reporting.

On April 25, 2014, the Central Bank of Brazil published resolutions relating to the financial institution's socio-environmental responsibility which also lists guidelines for applying socio-environmental responsibility policies. ${ }^{44}$ The National Development Bank is a major investor in green sectors. As per its resolutions, banks are required to be involved in E\&S stress testing and incorporate $\mathrm{E} \& \mathrm{~S}$ risk in their capital requirements.

\footnotetext{
${ }^{41}$ Rezwan ul Haque Aubhi, "The Evaluation of Green Banking Practices in Bangladesh," Research Journal of Finance and Accounting 7, no. 7 (2016): 93-125. 


\section{Green Finance for Sustainable Development in Pakistan}

Subsequently, banks are implementing socio-environmental responsibility policies as advised by the central bank. However, little evidence is found in terms of these initiatives contributing to green lending.

In 2014, Mongolia established the sustainable finance principles and sector guidelines which provide a framework to integrate E\&S considerations into lending decisions and product design. ${ }^{45}$ The Federation of Egyptian banks formed a sustainable development committee in 2014 to formulate green banking policies which emerged as a path towards achieving green growth sustainable development. ${ }^{46}$ They are in the process of formulating green banking guidelines so that borrowers are likely to be evaluated on this basis. This effort will help promote green banking development in the country.

The State Bank of Vietnam formulated an action plan in 2015 for green banking and set different priority areas for its promotion. ${ }^{47}$ To comply with this, banks are exploring the possibilities of green finance at different levels, however, the State Bank is concerned with undertaking ESG measures so that banks may have the ability to evaluate borrowers under new procedures. Using the large-scale survey from 32 banks and 329 respondents and applying exploratory factor analysis and regressions during 2016, researchers ${ }^{48}$ found that an understanding of green banking, current activities of green banking, and the priority sectors have positively influenced the willingness of Vietnamese banks to follow banking practices; however, the obstacles have been inversely associated with the propensity to employ green banking services. Among others, Pakistan was the late comer to launch their green finance practices in 2017. Banks/DFIs are currently developing their policy framework so as to cover the terms

\footnotetext{
${ }^{45}$ Mongolian Bankers Association, "Mongolian Sustainable Finance Principles Guidelines," (2014), https://mba.mn/sustainable-finance-in-mongolia/.

${ }^{46}$ H. Mounir, "Egyptian Banks Find their Way towards Green Banking as Path to Sustainable Development," Daily News Egypt, October 25, 2018, https://ww.dailynewssegypt.com/2018/10/25/egyptian-banks-find-their-way-towardsgreen-banking-as-path-to-sustainable-development/.

47 Tran Thi Thanh Tu and Tran Thi Hoang Yen, "Green Bank: International Experiences and Vietnam Perspectives," Asian Social Science 11, no.28 (2015): 188-199, doi:10.5539/ass.v11n28p188.

${ }^{48}$ Tran Thi Thanh Tu and Nguyen Thi Phuong Dung, "Factors Affecting Green Banking Practices: Explanatory Factor Analysis on Vietnamese Banks," Journal of Economic Development 24, no. 2 (2017): 4-30. doi: 10.24311/jed/2017.24.2.05.
} 
and conditions set by the SBP. The process of green banking is slow; however, it could contribute to overcome environmental issues in the country.

In short, the review of green finance policies suggests that China and India have made progress to develop and implement procedures in this regard. However, other countries which we reviewed are far behind in terms of their development and implementation of green finance practices because they may face many concerns to apply these procedures (e.g. banks do not have the capacity to evaluate the borrower under environmental friendly conditions, banking employees are not trained, lack of accountability, borrowers are unaware of how to adopt necessary measures to comply with environmental procedures, etc.). These issues may indicate that a lot of efforts are required by both banks and borrowers to understand the benefits of green finance so it can be implemented in its true spirit.

\section{Conclusion}

Since the Twentieth Century, rapid industrialisation around the world has created various environmental as well as climate issues. Without establishing specific guidelines and procedures, the GHG emissions will have adverse impact on the environment in developing countries. To cope with these concerns, the concept of Green Finance was introduced in 2009. Under this scheme, banks are required to evaluate borrowers in terms of environmental measures taken.

The purpose of this study has been to analyse the mechanism of Green Finance for sustainable development in Pakistan. In 2017, the SBP introduced Green Finance Guidelines which mainly focus on a risk management process that measures and examines environmental risks that can be generated from business activities. The objective of Green Finance is to ensure that an environmental risk management system is followed by banks/DFIs which may help to minimise environmental risks. This process broadly covers identification of risk parameters and the evaluation of potential consequences associated with these risks. This study explored the supply and demand side of Green Finance in Pakistan which highlighted various potential issues faced by the banks and borrowers. In 


\section{Green Finance for Sustainable Development in Pakistan}

addition, it also reviewed the policies of Green Finance among developing countries, and suggests that China and India have sufficient resources and know-how to implement green policies which help to overcome environmental issues. Moreover, it has been found that other developing countries in the sample are taking necessary measures to fulfill the requirements of green policies. In Pakistan, banks/DFIs are formulating Green Finance policies so that borrowers can be assessed under this new methodology. However, banks as well as regulators are required to support implementation of the entire process. Additionally, the scope of implementing Green Finance is huge since it can not only help overcome environmental issues on the one hand, and also make the firms more competitive in terms of reducing energy emissions on the other.

However, for this to work, the SBP needs to take vital steps: First, the SBP should devise a mechanism for monitoring the process over the life of financing so that firms comply with business processes. Second, banking personnel have insufficient knowledge to coordinate transactions which relates to Green Finance. It is, thus, important that employees should be engaged and properly trained to comprehensively understand and apply Green Finance policies. Third, the purpose of green technology should be clearly explained to stakeholders so that they can modify their business strategies as well as requirements. Fourth, the SBP should clarify the required levels of compliance to determine whether Green Finance policies can be fully or partially applied. Fifth, the mechanism for introducing innovative financial products is not identified, for instance, the issuance of green IPOs, green bonds, green funds, etc. Lastly, efforts are essential to create awareness about the concept of green finance among different stakeholders, not just within the banking and regulatory sector. If the recommendations in this study are considered, it will help to promote and boost green business in Pakistan. From a social perspective, Green Finance will promote a green environment in the country. There is also a need for conducting systematic empirical analyses to determine the impact of Green Finance on the factors that cause environment challenges within the country. 
Dr Muhammad Zubair Mumtaz \& Dr Zachary Alexander Smith

\section{Acknowledgement}

The authors are grateful for the valuable feedback that was given by the editor and three anonymous referees and believe that the manuscript benefitted greatly from their comments and suggestions. 